\title{
EFFECT OF INCLUSION CALCIUM-PALM FATTY ACID (CA-PFA) ON GROWTH PERFORMANCE AND PROFILE OF BODY FATTY ACID OF BROILER
}

\author{
G. A. M. K. Dewi, P. A. Astawa and I. K. Sumadi \\ Faculty of Animal Science, Udayana University, \\ Jln. PB. Sudirman, Denpasar, Bali - Indonesia. \\ CorrespondingE-mail: elly_unud@yahoo.com
}

Received October 30, 2010; Accepted February 02, 2011

\begin{abstract}
A study of effect of inclusion of calcium-palm fatty acid (Ca-PFA) in the diets on growth performance and profile of body fatty acid has been conducted for 4 weeks in broiler. A total of 160 birds were used in present experiment which was arranged in a Completely Randomized Design with 4 treatments and 5 replications ( 8 birds each). Dietary inclusions of Ca-PFA of $0,5,10$ and 15\% were reflected as R0, R1, R2 and R3, respectively. Results of the experiment showed that growth performance based on the feed consumption significantly decreased $(p<0.05)$, but there were no significant $(p>0.05)$ effect for final body weight, carcass percentage and carcass composition. The inclusion of Ca-PFA in the diet was not affected the saturated fatty acid $(p>0.05)$, but showed significant effect on unsaturated fatty acid and omega-3 fatty acid $(\mathrm{p}<0.05)$. Body fat distribution was not affected by inclusion level of CaPFA at a level of $15 \%$. In conclusion, the inclusion of Ca-PFA in the diet until $15 \%$ decreased feed consumption and produced similar growth performance, however it increased unsaturated fatty acid, omega-3 fatty acids and decreased body fat of broiler.
\end{abstract}

Keywords: body fat, broiler, calcium-palm fatty acid (Ca-PFA), carcass

\section{INTRODUCTION}

Chickens meat and eggs are the major protein source and have very high nutritive values for consumers. Chickens meat consumption has been increasing during the last few years due to the rise in health awareness (Barroeta, 2007). Poultry meat, as well as other meats, is a good source of high bioavailability in lower quantities than red meats. Broiler food as a source of protein has a genetically given the rapid growth when fed with the standard requirement.

Indonesia is the country producing the high crude palm oil (CPO) in the world with a total production of 19 ton recorded in 2009 (United States Departement of Agriculture, 2009). Palm fatty acid (PFA) that available in liquid form are major of palm cooking Bimoli oil Industry, and it is abundantly available in Indonesia. However through a chemical reaction process, PFA (liquid) can be changed into solid or powder in the form of protected fat product called calcium-fatty acid (Ca-PFA) (Dewi and Sinlae, 2004).

Ca-PFA is form of flour, whitish yellow color containing $5.97 \%$ calcium and gross energy of $7033 \mathrm{kcal} / \mathrm{kg}$. According to Dewi (2005), chromatographic profile analysis showed that $\mathrm{Ca}$ -
PFA content was oleic fatty acid (33.05\%) and linoleic $(6.95 \%)$. Essential fatty acids are needed in the ration of growing and laying chickens. Poultry can not synthesize essential fatty acids in the body, but can get it from fat resources on diet. It has been reported that the increase supply of dietary fatty acids on the diet can be used as precursor for the synthesis of meat fatty acids (Saify et al., 2003). Scaife et al. (1994) reported that essential fatty acid in diet can influence the fatty acid content of chicken meat. Furthermore, Lopez-Ferrer et al. (2000) and Crespo and Gracia (2002) reported that the fatty acid profile of feed consumption directly affects to the fatty acid composition of poultry body fat.

Nowadays, body fat content of broiler becomes a serious problem in human due to associated with high blood pressure, cholesterol and heart disease. Consumers want broiler meat containing low fat. Some efforts to produce meat of chicken containing low fatty acid that desired by consumers have been carried out.

The objective of this study was to study the influence of the use of Ca-PFA in the ration on broiler's growth performance (final body weight, carcass yield, carcass composition), fatty acid content of meat and body fat distribution. 


\section{MATERIALS AND METHODS}

\section{Birds and Treatments}

The 160 broiler were used as research materials. The broiler were divided to 4 treatments with 5 replicates of 8 birds each following Completely Randomized Design. The treatments were as follows, $\mathrm{R} 0$ : diet without $\mathrm{Ca}$ PFA; R1: diet with 5\% Ca-PFA; R2: diet with $10 \%$ Ca-PFA and R3: diet with $15 \%$ Ca-PFA.

Diets were formulated to be iso-caloric and iso-protein (2985 kcal $/ \mathrm{kg} \mathrm{ME}$ and 21\% CP) using the following ingredients in Table 1. Cage litter in size of $2 \mathrm{~m} \times 2 \mathrm{~m}$, provided a feeder and waterer were used. Diet and drinking water were provided ad libitum.

\section{Trait Measured}

Body weight and feed intake were recorded weekly by weighing all the birds and feed residue by an electronic weighing balance. At the end of the experiment (4 weeks), one broiler of each treatment groups were slaughtered. The carcasses were expressed as percentage of live body weight. The abdominal fat was removed and weighed to determine the percentage of abdominal fat. The yield of breast meat and abdominal fat were expressed as proportions of live weight.

Meat $(\%)=\{[$ Meat weight $(\mathrm{g})] /[$ body weight $(\mathrm{g})]\} \mathrm{x}$ $10 \times 100$

Abdominal fat $(\%)=\{[$ Abdominal fat weight $(\mathrm{g}) /$ [Body weight $(\mathrm{g})]\}$ x 100

Bone $(\%)=\{[$ Bone weight $(\mathrm{g})] /[$ body weight $(\mathrm{g})]\} \mathrm{x}$ 100

Fatty acid composition of meat was determined by gas cromatography with a Hewlett - Packarrd Model 5890 A.

The data were analyzed by Anova and mean comparison was tested by Multiple Range Test (Steel and Torrie, 1990).

\section{RESULTS AND DISCUSSION}

The effect of ration treatment on feed consumption, final body weight, carcass yield, and carcass physical composition of broiler are shown in Table 2.

\section{Growth Performance}

The inclusion of $5 \%$ Ca-PFA in the diet had significant effect $(p<0.05)$ on the feed consumption of broiler. The gradual decrease in feed intake with increase in the level of Ca-PFA feed is shown in Table 2. Experimental results showed that the consumption of Ca-PFA had the physiological effect on digestive system and increased metabolism of the chickens. According to Gollian and Maurice (1992) cited by Zulkifli (2007), the high metabolism required constantly food availability, it is believed that fat content in diet slow the passage rate of the diet in the intestine, resulting in longer nutrient absorbtion time.

Table 2 presents the effect inclusion of $\mathrm{Ca}$ PFA on final body weight. Inclusion Ca-PFA until $15 \%$ on diet had no significant effect $(\mathrm{p}>0.05)$ on final body weight. It was assumed that inclusion Ca-PFA in the diets did not cause body weight decrease. Similar research conducted by Sundu et al. (2005) showed that poultry given $40 \%$ of palm cernel meal did not decrease body weight.

Carcass percentage of broiler that received $15 \%$ of Ca-PFA was $66.65 \%$. This result indicated that giving $15 \%$ to broiler did not affect carcass percentage of birds. This result was similar to report of Bidura and Mahardika (2000). According to Zulkifli et al. (2003), the high fat diet alleviates the detrimental effects of heatstress and did not differ significantly in weight and carcass yield of broiler. Percent of meat, bone and skin are presented in Table 2. Experimental results showed that the inclusion of 5, 10 and $15 \%$ Ca-PFA did not affect the percentage of carcass composition.

This research focused on the use of dietary strategies to improve the quality of the poultry carcass. One of this modification was to increase the amount of unsaturated fatty acid, especially omega-3 which has beneficial effects on human health. This was in line with Barroeta (2007) that fat content in poultry meat is relatively low (2.8 $\mathrm{g} / 100 \mathrm{~g}$ breast, $13 \mathrm{~g} / 100 \mathrm{~g}$ thigh) and positive for a human health. According to Dewi (2010), kampung chicken fed ration containing energy $(3200 \mathrm{kcal} / \mathrm{kg})$ and protein $(22 \%)$ had no significant effect on carcass composition.

\section{Fatty Acid Content in Broiler Meat}

Structure and properties of fatty acids can be seen from saturated fatty acids, unsaturated fatty acids and omega-3 (Table 3). The mean of saturated fatty acid content of broiler meat with calcium palm-fatty acid (Ca-PFA) were between $34.04 \%$ and $35.60 \%$. Results showed no significant different $(\mathrm{p}>0.05)$ among treatments. 
Table 1. Composition of the Ration

\begin{tabular}{|c|c|c|c|c|}
\hline \multirow{2}{*}{ Ingredient } & \multirow{2}{*}{ Control (R0) } & \multicolumn{3}{|c|}{ Ca- Palm Fatty Acid (Ca-PFA) } \\
\hline & & $5 \%(\mathrm{R} 1)$ & $10 \%(\mathrm{R} 2)$ & $15 \%(\mathrm{R} 3)$ \\
\hline & \multicolumn{2}{|c|}{ 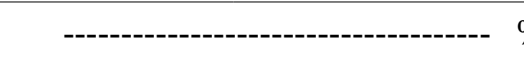 } & ------- & ----- \\
\hline Corn & 50.53 & 48.29 & 37.41 & 25.20 \\
\hline Soybean meal & 28.45 & 30.88 & 36.11 & 35.71 \\
\hline Rice bran & 10.00 & 10.00 & 10.00 & 10.00 \\
\hline Ca-PFA & - & 5.00 & 10.00 & 15.00 \\
\hline Pollard & - & - & 3.16 & 17.07 \\
\hline CGM & 4.00 & 2.69 & - & - \\
\hline Dicalsium Fospat & 2.05 & 2.05 & 2.02 & 1.84 \\
\hline Limestone & 1.00 & 0.19 & 0.64 & 0.12 \\
\hline Salt & 0.42 & 0.29 & 0.18 & 0.42 \\
\hline Choline & 0.08 & 0.08 & 0.08 & 0.08 \\
\hline Coksidiostat & 0.05 & 0.05 & 0.05 & 0.05 \\
\hline Mineral B12 & 0.04 & 0.04 & 0.04 & 0.04 \\
\hline Rhodiamix & 0.02 & 0.02 & 0.02 & 0.02 \\
\hline Antibiotic & 0.02 & 0.02 & 0.02 & 0.02 \\
\hline \multicolumn{5}{|c|}{ Nutrition Content of Ration *) } \\
\hline Dry Matter (\%) & 87.20 & 87.42 & 88.25 & 88.97 \\
\hline $\mathrm{ME}(\mathrm{kcal} / \mathrm{kg})$ & 2985 & 2985 & 2985 & 2985 \\
\hline Crude Protein (\%) & 21.00 & 21.00 & 21.00 & 21.00 \\
\hline Crude Fiber (\%) & 3.32 & 3.38 & 3.67 & 4.16 \\
\hline Fat (\%) & 6.85 & 8.19 & 12.18 & 14.24 \\
\hline Ash (\%) & 6.24 & 5.40 & 5.91 & 5.29 \\
\hline $\mathrm{Ca}(\%)$ & 0.90 & 0.90 & 0.90 & 0.90 \\
\hline $\mathrm{P}(\%)$ & 0.45 & 0.45 & 0.45 & 0.45 \\
\hline Lysin $(\%)$ & 1.18 & 1.18 & 1.18 & 1.18 \\
\hline Metionine (\%) & 0.57 & 0.57 & 0.57 & 0.57 \\
\hline
\end{tabular}

*) Standard according to Scott et al. (1992)

All treatments use Ca-PFA containing saturated fatty acid less than $40 \%$. According to Crespo and Garcia (2002), saturated fatty acid can be synthesized in broiler fed diets containing oil. Santoso et al. (2010) reported that supplementation of Sauropus androgenus extract and Lemuru fish oil reduced fat deposition and meat cholesterol in broiler meat. Leaf et al. (1995) dicussed that consumption of n3-PUFA from fish might reduce of coronary heart disease.

The highest content of unsaturated fatty acid was in $10 \%$ Ca PFA (R2), whereas the lowest was in treatment $0 \%$ Ca-PFA (R0). Statistical analysis showed that content of unsaturated fatty acid at R0 and R1 was significantly different from R2 and R3 $(p<0.05)$. The higher level of Ca-PFA in broiler diets has increased unsaturated fatty acid content of meat. Ration containing fatty acid can be stored in the form of the same fatty acid (Scaife et al., 1994). Unsaturated fatty acid is more easily formed miselle with bile salts compared to saturated fatty acids (Cortinas, 2004). Chicken meat can be used as a source of essential fatty acids in humans

The omega-3 fatty acid content of broiler meat is presented in Table 3 . The broiler meat containing highest omega-3 fatty acid was found in the R3 and the lowest was in R0. There was significant difference between treatment of $15 \%$ Ca-PFA (R3) and R0, R1 and R2. The content of 
Table2. Feed Consumption, Final Body Weight, Carcass Percentage and Carcass Composition of Broiler

\begin{tabular}{lcccc}
\hline \multirow{2}{*}{ Parameter } & \multicolumn{3}{c}{ Ca- Palm Fatty Acid (Ca-PFA) } \\
\cline { 2 - 4 } & Control (R0) & $5 \%(\mathrm{R} 1)$ & $10 \%(\mathrm{R} 2)$ & $15 \%(\mathrm{R} 3)$ \\
\hline Feed Consumption $(\mathrm{g})$ & $1733^{\mathrm{a}}$ & $1750^{\mathrm{b}}$ & $1740^{\mathrm{a}}$ & $1722^{\mathrm{a}}$ \\
Final body weight (g) & 1120 & 1140 & 1195 & 1198 \\
Carcass Percentage (\% carcass) & 66.27 & 66.30 & 66.42 & 66.65 \\
Carcass composition (\% carcass) & & & 58.78 & 59.26 \\
Meat (\%) & 58.54 & 58.75 & 27.38 & 27.40 \\
Bone (\%) & 27.57 & 27.37 & 13.84 & 13.34 \\
Skin included sub cutaneus fat (\%) & 13.89 & 13.88 & & \\
\hline
\end{tabular}

Mean with different superscript in the same row indicates significant $(\mathrm{p}<0.05)$; R0 = rations with $0 \%$ Ca-PFA; R1

$=$ Ration with $5 \%$ Ca-PFA; R2 = ration with $10 \% \mathrm{Ca}-\mathrm{PFA}$ and $\mathrm{R} 3=$ ration with $15 \% \mathrm{Ca}-\mathrm{PFA}$

Table 3. Fatty Acid Content of Meat and Body Fat Distribution of Broiler

\begin{tabular}{lcccc}
\hline \multirow{2}{*}{ Parameter } & \multicolumn{4}{c}{ Ca- Palm Fatty Acid (Ca-PFA) } \\
\cline { 2 - 5 } & Control (R0) & $5 \%(\mathrm{R} 1)$ & $10 \%(\mathrm{R} 2)$ & $15 \%(\mathrm{R} 3)$ \\
\hline Fatty acid content of meat & 35.60 & 34.25 & 34.32 & 34.04 \\
$\quad$ Saturated fatty acid (\%) & $64.34^{\mathrm{a}}$ & $64.79^{\mathrm{a}}$ & $65.60^{\mathrm{b}}$ & $65.28^{\mathrm{b}}$ \\
Unsaturated fatty acid (\%) & $5.48^{\mathrm{a}}$ & $5.60^{\mathrm{a}}$ & $5.85^{\mathrm{a}}$ & $6.10^{\mathrm{b}}$ \\
Omega -3 fatty acid (\%) & & & & \\
Distribution of body fat (\%) & 1.64 & 1.54 & 1.58 & 1.60 \\
Gizzard fat & $0.35^{\mathrm{b}}$ & $0.28^{\mathrm{a}}$ & $0.28^{\mathrm{a}}$ & $0.26^{\mathrm{a}}$ \\
Mesentrium fat & $1.46^{\mathrm{b}}$ & $1.35^{\mathrm{a}}$ & $1.37^{\mathrm{a}}$ & $1.39^{\mathrm{a}}$ \\
Pad fat & 2.08 & 2.03 & 2.25 & 2.01 \\
Abdominal fat & 8.00 & 8.2 & 8.5 & 8.8 \\
Score of shank color & &
\end{tabular}

Mean with different superscript in the same row are significant $(\mathrm{p}<0.05)$

omega- 3 chicken meat can be caused by fatty acid content on the diet consumed. Since essential fatty acids did not synthesized in the body, so that the use of $15 \%$ Ca-PFA (R3) can increase the omega3 fatty acids of meat. N-3 family included linoleic acid derived from vegetable fats can increase the omega-3 fatty acids chicken tissue (Lopez-Ferrer et al., 2000). Those nutrients (amino acid and fatty acid) are essential not only for normal performance but also for synthesis of many bioactive compounds (Wu and Self, 2005).

\section{Body Fat Distribution of Broiler Chicken}

The percentage of fat in broiler gizzard in R0 was $1.64 \%$ of slaughter weight (Table 3 ).
There was no significant difference $(\mathrm{p}>0.05)$ among the treatments. This could be due to calcium-fatty acids ration used for growth and excess a small amounts fat is stored in the gizzard fat.

The percentage of broiler fat in mesentrium receiving feeding treatment R0 was $0.35 \%$. Results showed significant differences $(p<0.05)$ between R0 and treatment using 5, 10 and $15 \%$ of Ca-PFA in the ration. The highest percentage of pads fat was $1.46 \%$ on broiler that are treated without the addition of Ca-PFA (R0).

Results showed the percentage of abdominal fat of broiler was no significant differences $(p>0.05)$ among the rations (Table 3$)$. In general, 
the use of calcium-fatty acid in the ration decreased fat distribution in the chicken body. In this case, perhaps Ca-PFA on the diet consumed and absorbed, were all used well for chicken growth. Factors that may affect the accumulation of body fat in chicken is age, body weight, energy level of feed (Scaife, 1994) and in relation to the different tissues, modification of FA composition of intramuscular fat is more limited than the separable fat depots such as abdominal and sub cutanious fat (Cortinas et al. 2004).

The shank color of broiler chickens receiving the treatment of Ca-PFA varied at range of score 8.0 - 8.8 'yolk color fan' and the highest was obtained by the treatment R3 (amounted to 8.8 score). Results showed no significant differences ( $>0.05$ ) among rations. Factors that may affect the shank color on body chicken are feed, health and genetic of bird. The use oCa-PFA in the ration gave high carotene, carotene and xantopil that increased increase shank color (Dewi, 2010). Isroli et al.(2010) studied that supplementation of $30 \%$ batatas meal increased yellow color in egg of local duck.

\section{CONCLUSION}

The inclusion of calcium-palm fatty acid (Ca-PFA) in the diet up to $15 \%$ decreased feed consumption and produced similar growth performance. However, it increased unsaturated fatty acid, omega-3 fatty acids and decreased body fat of broiler.

\section{ACKNOWLEDGMENT}

The authors thanks to the head of chicken farm and staff Laboratory for chemical analysis BPPT-Ciawi, Bogor, who helped for the collecting data and completion of this writing.

\section{REFERENCES}

Bidura, I. G. N. G. and I. G. Mahardika. 2000. Penggunaan tepung jerami bawang putih (Allium sativum) dalam ransum terhadap berat potong dan komposisi fisik karkas itik. Majalah Ilmiah Peternakan. 3 (3):67-71

Borroeta, A. C. 2007. Nutritive value of poultry meat: Relationship between vitamin E and PUFA: World's Poultry Science Association. 63: 277-284.

Cortinas, I., C. Villaverde. J. Galobart, M.D. Baucells, R.Codony and A. C. Barroeta.
2004. Fatty acid content in chicken thigh and breast as affected by dietary polyunsaturation level. Poult. Sci. 83: 1155-1164.

Crespo, N. and E.Garcia. 2002. Dietary linseed oil produces lower abdominal fat deposition but higher de novo fatty acid synthesis in broiler chickens. Poult. Sci. 81: 1555-1562.

Dewi, G.A.M.K and M. Sinlae. 2004. The effect of palm fatty acid (PFA) and calcium palmfatty acid (Ca-PFA) on performance of broiler chicken. Proceedings of the $11^{\text {th }}$. Animal Science Congress (AAAP), Kualalumpur, Malaysia. II: 135-157

Dewi, G. A. M. K. 2005. Pengolahan limbah Bimoli (asam lemak sawit) dan penggunaannya untuk ayam. Buletin Nutrisi, Fapet UNDANA, Kupang. 8: 4-8.

Dewi, G. A. M. K. 2010. Pengaruh penggunaan level energi - protein ransum terhadap produksi karkas ayam Kampung. Prosiding Seminar Nasional Unggas Lokal ke IV, Fakultas Peternakan UNDIP, 7 Oktober 2010. Page $222-228$.

Gollian, A. and D. V. Maurice. 1992. Dietary poultry fat and gastro intestinal transit time of feed and fat utilization in broiler chickens. Poult. Sci. 71:1357-1363.

Isroli, A. Setyono, H. Rizqiati, S. Susanti dan T. A. Sarjana. 2010. Pengaruh suplementasi tepung ubi jalar (Ipomea batatas) dalam ransom terhadap kualitas telur itik lokal. Prosiding Seminar Nasional Unggas Lokal ke IV, Fakultas Peternakan UNDIP, 7 Oktober 2010. Page 229 - 234.

Leaf, D. A., W. E. Connor, L.Barstand and G. Sexton. 1995. Incorporation of dietary n-3 fatty acids into the fatty acids of human adipose tissue and plasma lipid classes. Am. J. Clin. Nutr. 62: 68-73.

Lopez-Ferrer, S., M. D. Baucells, A.C. Barroeta and M.A. Grashorn. 2000. Influence of vegetable oil sources on quality parameters of broiler meat. Archiv fur Geflugelkunde. 63: 29-35.

Santoso, U., Kususiyah and Y. Fenita. 2010. The effect of Sauropus androgynus extract and lemuru oil on fat deposition and fatty acid composition of meat in broiler chickens. J. Indonesian Trop. Anim. Agric. 35(1):48-54.

Saify, Z. S., S. Akhtar, K. M. Kham, S. Perveen, S. A. M. Ayattallahi, S. Hassan, M. Arif, S. M. Haidar, F. Ahmad, S. Siddiqui and M. Z. Khan. 2003. A study on the fatty acid composition of fish liver oil from two marine 
fish, euspyra blochii and carcharhinus bleekeri. Turkey J. Chem. 27:251-258.

Scaife, J.R., J. Moyo, H. Galbrainth, W. Michie and V.Campbell. 1994. Effect of different dietary supplemental fats and oils on the tissue fatty acid composition and growth of female broiler. Br. Poult. Sci. 35 : $107-118$.

Scott, M. L., M.C.Nesheim, and R.J.Young. 1992. Nutrition of the Chicken. $3^{\text {rd }}$ Ed.M. L. Scott and Associates, Ithaca, New York.

Steel, R. G.D. and J. H. Torrie, 1990. Principle and Procedures of Statistics. Second Edition. McGraw-Hill Book Company Inc., New York.

Sundu, B., A. Kumar and J. Dingle. 2005. Response of bird fed increasing in levels of palm kernel meal supplemented with enzymes. Aust. Poult. Sci. Symposium 17:227-228.
United States Department of Agriculture. 2009. Indonesia: Palm Oil Production Growth to Continue. Foreign Agriculrure Service. March Issue 2009. United States Departement of Agriculture. USA.

Wu, G. and J.T. Self. 2005. Amino acid: Metabolism and fuctions. In: Encyclopedia of Animal Science (Ed. W. G. Pond and A. W. Bell). Marcel Dekker. Inc., New York. Pp: $9-12$.

Zulkifli, I.,J. Ginsos, P. K. Liew and J. Gilbert, 2003. Growth performance and Newcastle disease antibody tittres of broiler chickens fed palm-based diets and their response to heat stress during fasting. Arch. Gefflugelk. 67:125-130.

Zulkifli,I., Nwe New Htin, A.R. Alimon,T.C. Loh and M. Hair-Bejo. 2007. Dietary selection of fat by heat-stressed broiler chickens. AsianAust. J. Anim. Sci. 20(2):245-251. 